\begin{tabular}{|c|c|}
\hline \multirow{3}{*}{ 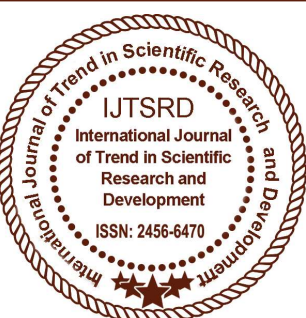 } & $\begin{array}{l}\text { International Journal of Trend in Scientific } \\
\text { Research and Development (IJTSRD) }\end{array}$ \\
\hline & International Open Access Journal \\
\hline & ISSN No: 2456 - 6470 | www.ijtsrd.com | Volume - 2 | Issue - 5 \\
\hline
\end{tabular}

\title{
A Reflection on the Procedure for the Arrest of a Vessel Under the CEMAC Marine Merchant Code 2012 within Cameroons Territorial Waters and Post Arrest Issues
}

\author{
Dr. Mantinkang Formbasso Lawrence Ph.D \\ Senior Lecturer, Faculty of Law and Political Science, \\ University of Ngaoundéré, Cameroon
}

\begin{abstract}
As a littoral State with a long coastlines and a huge interest in the Atlantic ocean Cameroon has the responsibility to dispense justice with regard to matters pertaining to the waters under her control. Ship arrest within the waters of Cameroon is done in compliance with the procedure put in place by the CEMAC Marine Merchant Code 2012 and the 1999 Arrest Convention. These texts form part and parcel of Cameroons' legislation. Courts charged with the responsibility of ship arrest in Cameroon are the Court of First Instance and the High Court. Ship arrest in Cameroon is actually effected by a competent maritime authority following the order of a competent court. The arrest can either on the basis of saise conservatoire or saise vente. The courts often strive to protect the rights of third parties when a ship is arrested. This paper has as objective to examine the mechanisms for the arrest of a vessel within the maritime waters of Cameroon as provided by the maritime texts in force.
\end{abstract}

Keywords: Procedure, Arrest, Jurisdiction, Admiralty law, Security, Priority, Responsibility

\section{INTRODUCTION}

To start with the mechanism for the arrest of a ship without a brief reference to the admiralty jurisdiction will, in the words of Mbah Ndam, tantamount to a house without foundation ${ }^{1}$. Admiralty jurisdiction in Cameroon is exercised by the Courts of First Instance

\footnotetext{
1 Joseph Mbah-Ndam, Practice and Procedure in Civil and Commercial Litigation, Press Universitaires d'Afrique. 2003. p. 9.
}

(the Magistrate Courts) and the High Courts ${ }^{2}$. By article 796 of the Code Communuataire de la Marine Marchande of the Communaute Economique et Monetaire de l'Afrique Centrale (CEMAC) ${ }^{3}$, a maritime commercial court or a maritime chamber shall be instituted within commercial courts or courts of original jurisdiction to entertain maritime litigations. In Cameroon, the courts with original jurisdiction competent to entertain maritime litigations are those mentioned herein above. The jurisdiction of the admiralty courts in Cameroon extends to all ships within the territorial waters of Cameroon. This is so irrespective of the residence or domicile of the owners. It is important to point out here that admiralty jurisdiction is not limited to arresting a ship but extends to maritime claims as provided by article 149 of the CEMAC Marine Merchant code 2012.

The focus of this paper is to examine the mechanism for the arrest of a vessel within the CEMAC subregion as provided by the regional marine merchant code. To achieve the objective of this article i shall consider among other issues, how the in rem form is

\footnotetext{
The amount of claim leading to the arrest of a vessel will determine which of these courts is competent. Where the claim is inferior to ten million francs $(10,000,000)$ the competent court is the court of first instance and other wise is the High court. The material competence of these courts are provided in sections 15 (1) (b)-ii and 18 (1) (b)-ii (respectively for the Court of First Instance and the High Court) of Law $\mathrm{N}^{\mathrm{o}} .2006 / 015$ of $29^{\text {th }}$ December 2006 on Judicial Organisation in Cameroon as amended in 2011.

${ }^{3}$ In this article the code communautaire is referred to as CEMAC Marine Merchant Code 2012
} 
issued, its service and the arrest of the vessel. Furthermore the article will address possible post arrest issues like the rights of third parties, provision of security for the claim and release from arrest, wrongful arrest and its effects, possibility of re-arrest, re-arrest with leave of court and then re-arrest and risk management.

\section{Issue of the in rem Form, Service and Arrest 1.1 Issue of the Form}

A claim in rem is always initiated by the issue of an in rem form ${ }^{4}$. The form can name more than one ship, or separate forms may be issued against different ships belonging to the same owner for the same claim, but only one ship can be arrested ${ }^{5}$. In The Berny ${ }^{6}$, it was held that cargo-owners were entitled to institute proceedings in rem against more than one ship, provided they served proceedings on, or arrested, only one of such ships. From this decision it is clear that a claimant can elect which ship to arrest from among a fleet. In practice, the claimant would wait until one of the ships named comes within jurisdiction, in which case he will amend the claim form accordingly and serve it on the ship.

The effect of issue of a claim form is to crystallise the claimant's statutory right in rem against the relevant ship. This crystallisation has as consequence, the protection of the claimant's right in that, should ownership be transferred even to a bona fide purchaser before service of the form, the claimant's claim will remain enforceable against the ship by service and arrest.

\subsection{Service of the Form}

This can be effected either upon the property by affixing the claim form or a copy on the outside of the property in a position where it is reasonably expected to be seen; or upon the defendant's solicitor who has authority to accept service. Trite to note is that service does not constitute an arrest. A warrant of arrest has to be issued in a separate application and executed by the Admiralty Marshal or his substitute. The effect of service is that the jurisdiction of the court is invoked ${ }^{7}$. In addition, the person named in the claim form as one to be liable in personam becomes a party to the proceedings. The claim will however not cease being one in rem.

\footnotetext{
4 See r. 61.3(2) of the English Civil Procedure Rules 1998.

5 See The Banco (1971) 1 Lloyd's Rep. 49.

6 (1977) 2 Lloyd's Rep. 533.

${ }^{7}$ The Freccia del Nord (1989) 1 Lloyd's Rep. 388.
}

The claim form cannot be served out of jurisdiction nor is an order for substituted service possible ${ }^{8}$. In most cases, it has been observed, when an undertaking is given by way of security for the claim to the claimant in an acceptable form prior to the service of proceedings and in lieu of arrest, there is a condition of the undertaking that solicitors will be appointed by the defendants to accept service unconditionally ${ }^{9}$. The solicitor's acceptance is indicated by endorsement on the claim form. This act amounts to submission to jurisdiction of the court by the defendant. On the other hand, the defendant may choose to acknowledge the issue of the claim form which will also amount to submission to jurisdiction ${ }^{10}$.

\subsection{Arrest}

Within the CEMAC zone and particularly in Cameroon, arrest ${ }^{11}$ is effected by the competent maritime authority following a judicial notification to that effect $^{12}$. Ship arrest in Cameroon as a conservatory measure is governed by the CEMAC legislation on marine merchant ${ }^{13}$. By virtue of this law, an arrest can be effected either on the ship from which the maritime claim arose or on sister ships belonging to the same owner ${ }^{14}$. Claims which may give rise to ship arrest in Cameroon as a conservatory measure are found under Article 119 of the Community Marine Merchant Code ${ }^{15}$.

${ }^{8}$ The Good Herald (1987) 1 Lloyd's Rep. 236.

9 Aleka Mandaraka-Sheppard, Modern Maritime Law and Risk Management (Routledge Cavendish, London 2007) 5. 116.

${ }^{10}$ R. 61.3(6) of the English Civil Procedure Rules 1998.

${ }^{11}$ Arrest can either be as a conservatory measure or executory measure. As a conservatory measure, it is interpreted to mean detention or restriction on removal of a ship by Court order to secure a maritime claim and as an executory measure; it will include seizure of a ship in execution or satisfaction of a judgement. S. 1 (2) of the International Convention on the Arrest of Ships 1999 describes both measures recognised in Cameroon. The person entitled to exercise ship arrest as an executory measure will be a holder of an executory title in view of having the ship sold. Article 157 of the CEMAC Marine Merchant Code 2012 outlines such executory titles.

${ }^{12}$ Art. 152 CEMAC Marine Merchant Code 2012. This code is community legislation applicable to the CEMAC member States.

13 Article 144 (1) (2) CEMAC Marine Merchant Code 2012.

${ }^{14}$ The above Article exclude Government owned vessels or vessels exploited for purely government services from being arrested.

15 This Code is purely in French and is referred to as Code Communautaire de la Marine Marchande adopted $22^{\text {nd }}$ July, 2012. The translation of the title or any Article of the Code is unofficial, it is meant only for the purpose of this article. 
As far as practice is concerned, the following claims have given rise to ship arrests within the Cameroonian admiralty jurisdiction:

1. Premiums owing as a result of insurance of ships;

2. Supply of paint to ships;

3. Delivery of various products such as petroleum and food items to ships;

4. Supply of petrol, gas, oil and advance payment to the owner of a ship;

5. Execution of a contract of representation and consignment; and

6. Claim by the crew who prove abandonment by the captain without any protection ${ }^{16}$.

The courts with competent jurisdiction to exercise arrest as a conservatory measure in Cameroon ${ }^{17}$ are the Courts of First Instance ${ }^{18}$ in Limbe, Bonanjo, and Kribi. This is done by way of petition to the president of the court, who then grants it in the form of a court order following the opinion of the competent maritime authority ${ }^{19}$. This order is granted as soon as a maritime claim appears founded. In practice, the opinion of the maritime authority is not binding on the judge $^{20}$. Petitions for arrest are filed on working days and during working hours. The arrest ${ }^{21}$ only prevents the ship from moving. It does not infringe on the right of the owner ${ }^{22}$. In a situation where the ship is flying a CEMAC member State's flag, the arrest report is registered in the register in which the ship was matriculated and kept by a competent maritime authority. The deadline for registration of the arrest report is seven (7) days. This can be extended to twenty (20) days where the place of arrest and that where the register of matriculation is kept are not within the same CEMAC State ${ }^{23}$.

In practice however, an arrest as a conservatory measure in Cameroon can also be done by the High Court. The case of Compagnie Professionnelle D'Assurance (CPA) S.A c/Zhao Yue Ping, Société the West of English Ship owners Mutual Insurance Association, Armateur M/V Luo Qing $^{24}$ wherein the plaintiff was paid damages amounting to $71,173,000$ FCFA is a pointer here. In this case, the plaintiff CPA sued the defendant in the High Court of Wouri for damage to and loss of tonnes of cement shipped from Europe to the Autonomous Port of Douala, Cameroon via ship $M / V$ Luo Qing. The consignment was packaged in 5400 big bags and insured by the CPA S.A. A good quantity of the cement was damaged and there was shortage when the goods were unloaded on the $21^{\text {st }}$ of November 2005 at the port in Douala. In order to secure payment of the sum of $71,173,000$ as evidenced by guarantee No. 05-92 of $30^{\text {th }}$ November 2005 by the defendants, the plaintiff prayed the court for the ship to be temporarily arrested. M/V Luo Qing was thus immobilised ${ }^{25}$ by court order as security for the plaintiff's claim. In as much as this judgement ${ }^{26}$ was good and respected by the defendant thereby operating as a precedent ${ }^{27}$, we wonder why the Judge made allusions to the French Code civil ${ }^{28}$ instead of the Code which was in force long before the case came up.

See Article 152 (4). Ibid.

24 Civil judgement No. 595 of $1^{\text {st }}$ August 2008.

25 Ship arrest as conservatory measure only prevents the ship from leaving the jurisdiction of the courts until the matter between her owner and the claimant is resolved. See Article 121 of the old Code. This situation is covered by Article 151 of the new CEMAC Marine Merchant Code. If the owner provides alternative adequate security while the matter is pending, the ship will undoubtedly be released from arrest to continue trading.

26 For the complete facts and judgement of this case which appeared in French see CPTE No. 930/06-07, ANNE 2008 NO 0168/RG/2008. Civil Judgement No. 595 of $1^{\text {st }}$ August 2008.

27 The doctrine of binding precedent is a feature of the common law and not of the civil law. Civilian judges can nevertheless make allusion to past cases but are not like their counterpart in common law bound to follow previous decisions.

28 Art. 1134 et seq.

22 See Article 151 of the 2012 CEMAC Marine Merchant code. 
Ship arrest under the CEMAC marine merchant code can also be done to execute a judgement ${ }^{29}$. In this instance, the arrest will be done as an executory measure. This entails restraining the ship by anybody holding an executory title in view of having the vessel sold. The executory titles are provided by the Code ${ }^{30}$. With any of the titles, a bailiff serves a formal notice to pay within thirty (30) days on the debtor failing which the same bailiff effects the arrest. The creditor will then have twenty (20) days to file his conditions and articles of arrest/sale at the registry of the competent High Court through his solicitor ${ }^{31}$.

Where an arrest as an executory measure is not preceded by an arrest as a conservatory measure, it is requested from a judge of a competent court in the conditions and according to the procedure in force for the seizure of immovable ${ }^{32}$. Upon the arrest, a report is written and a keeper designated under the same conditions as in ship arrest as a conservatory measure. The report must contain the following:

I. Name, profession and residence of the creditor upon whose instructions the bailiff is acting ${ }^{33}$;

II. Court decision authorising the arrest ${ }^{34}$;

III. Amount of claim justifying the arrest ${ }^{35}$;

29 See generally Chapter II of Book III of the 2012 Code. This chapter contain 18 articles which gives a detail procedure for the arrest of a ship to execute a judgement.

30 Article 157 of the 2012 Code by paragraph 2 of this article the following constitute executory titles:

- the jurisdictional decisions with the executory
formula and
- those which are enforceable on minutes;
- foreign judicial acts and decisions as well as
arbitral awards declared enforceable by a court
decision without suspense effect of execution of
the State in which the title is invoked;
- the conciliation minutes signed by the judge and
the parties;
- notarial deeds bearing the executory formula;
- the decisions to which the national law of each
State Party attaches the effects of a judicial
decision.

${ }^{31}$ Feh Henry Baaboh, 'Ship arrest as an Executory Measure in Cameroon'. A paper presented at the $5^{\text {th }}$ Members Meeting of SHIPARRESTED.COM. Riga in 2008.

${ }^{32}$ The Law applicable in cases of seizure of immovable property in Cameroon is the OHADA Uniform Act on Simplified Recovery and Measures of Execution 1998.

33 Article 152 (a).

34 Article 152 (b).

35 Article 152 (c).
IV. Date of the formal notice to pay which date preceded the arrest ${ }^{36}$;

V. Forum election done by the creditor in the competent jurisdiction and in the place where the ship is berthed ${ }^{37}$;

VI. Name and address of the owner(s) of the ship ${ }^{38}$; and

VII. Name, category, tonnage and nationality of the $\operatorname{ship}^{39}$.

In addition to the above details, the report must contain a statement and description of the launch, rigging and gear of the ship and which shall then be registered under arrest as a conservatory measure ${ }^{40}$.

By article 161 of the Code, the report of the arrest is recorded in the register of maritime mortgages kept by the competent administrative authority. This is required to be done within seven (7) days with effect from the date of arrest report. This deadline is however extended to fourteen (14) days ${ }^{41}$ where the register and the port of arrest are not in the same place. Thereafter, the registrar issues a status of record of mortgage charges to the creditor. Within a further period of seven (7) days, the arrest is notified to registered creditors recorded in the domicile elected in the records. If the elected domicile is not situated within the jurisdiction of the competent court ${ }^{42}$, the deadline is extended to fifteen (15) days ${ }^{43}$.

The application for ship arrest as an executory measure is filed before the President of the competent High Court following the procedure in the Uniform Act for attachment of real property. If there is more than one ship to be arrested, the application is filed in only one of the jurisdictions. Practice shows that if an application contains more than one ship belonging to same owner and for the same claim, only one of the ships can be arrested ${ }^{44}$. According to the Uniform Act,

36 Article 152 (d).

${ }^{37}$ Article 152 (e).

${ }^{38}$ Article 152 (f).

39 Article $152(\mathrm{~g})$.

40 For more on the content of this report, see Article 152 of the Code. Ibid.

${ }^{41}$ Article 161 of the 2012 Code

${ }^{42}$ The competent courts in matters of ship arrest as an executory measure is the Tribunal de Grand Instance in Bonnanjo Douala, Kribi and Garoua and the High Court in Buea.

43 Article 162 (2) of the 2012 Code.

44 The Banco(1971) 1 Lloyd's Rep. 49. In The Berny (1977) 2 Lloyd's Rep. 533, the court also held that cargo owners were entitled to institute proceeding in rem against more 
the arrest/sale procedure has eight steps which must be scrupulously followed.

\section{A. Formal notice to pay:}

This is served by the bailiff on the debtor after which the creditor has fifty (50) days to file an application for arrest/sale if payment is not delivered.

\section{B. Preparation and filing of the articles and conditions of arrest/sale:}

The filing is done at the registry of the competent High Court. The following detailed documents must be included in the articles and conditions for arrest/sale under pain of nullity:

$>$ Title of the act i.e. articles and conditions of arrest/sale;

$>$ The writ of execution justifying the arrest and the formal notice to pay / proof of service;

$>$ Indications as to the jurisdiction elected by the creditor or Notary Public chosen by the creditor and the debtor before whom adjudication would take place;

$>$ The name, nationality, date of birth and residence of the creditor;

$>$ The name, title and address of the solicitor of the creditor;

$>$ Designation of the ship under arrest as described in the formal notice to pay or a description of the ship by the bailiff;

$>$ The conditions of sale notably the rights and duties of the seller(s) and adjudicator(s)/buyer(s);

$>$ Details as to the cost of arrest/sale procedure;

$>$ The upset price fixed by the creditor which must be inferior to one quarter $(1 / 4)$ of the market value of the ship.

To these must be annexed all real charges encumbering the ship if any.

\section{Formal notice to debtor and other registered creditors:}

This is to inform them to obtain copies of the articles and conditions of arrest/sale from the court registry. The notice shall contain the following details under pain of nullity:

$>$ Date and hour of the hearing. The date must be thirty (30) days following the last formal notice;

$>$ Day and hour of adjudication which must be within the thirtieth $\left(30^{\text {th }}\right)$ and sixtieth $\left(60^{\text {th }}\right)$ day after the hearing date.

than one ship, provided they served proceedings on, or arrested, only one of such ships.

\section{The hearing:}

The right to fair hearing must be observed at the trial. When the price fixed is contested, the contesting party is free to apply to the court to appoint an expert to assess the value of the vessel. This will be at his expense.

\section{E. Formalities before sale/adjudication:}

Between fifteen (15) and thirty (30) days before adjudication, an extract of the articles and conditions of arrest/sale signed by the solicitor of the creditor must be published in an official newspaper and equally posted at the door of the residence of the debtor, the competent court or Notary Public agreed upon as well as in official places of the municipality where the ship is berthed. The publication must contain the following details:

The name, profession, residence of the parties and their solicitors;

$>$ Designation of the ship under arrest;

$>$ The setup price;

$>$ Indication as to the day, place and hour of adjudication;

The competent jurisdiction or the Notary Public to do the sale;

A bailiff's report justifying the legal publication including publication in official places.

\section{F. Sale proper:}

The conditions of sale of the ship are fixed by the competent court according to the procedure at common law applicable to forceful sale of realties. The notice is posted on the most conspicuous part of the ship, the main door of the court before which the sale would take place, in public places or the wharf of the port where the ship is berthed, at the Chamber of Commerce, at the customs office and at the headquarter of the maritime district of the place ${ }^{45}$.

Under English law, only the Admiralty Marshal or his substitute may effect an arrest of the property ${ }^{46}$. An application to arrest may be made by filing an application of notice to the Admiralty and Commercial Registry. Prior to such application, the applicant needs to carry out a search in the caveat book in order to verify whether there is any caveat against arrest. He will then file a declaration containing the particulars of the claim, the property to be arrested, and the amount of security.

\footnotetext{
45 Article 164 of the 2012 Code.

${ }^{46}$ R. 61.5(8) Civil Procedure Code 1998.
} 
The Admiralty Marshal or his substitute will then serve the warrant on the property to be arrested. An arrest can be prevented by filing a caveat against arrest in the Admiralty and Commercial Registry accompanied by an undertaking to file an acknowledgement of service and to give sufficient security to satisfy the claim with interest and costs. The issue of an arrest warrant at common law is as of right $^{47}$, save where the property in respect of which the beneficial ownership has since changed when the claim form was issued, as a result of a sale by any court in any jurisdiction exercising admiralty jurisdiction in $\mathrm{rem}^{48}$.

\section{Aftermath of Arrest}

Here we deal with possible post arrest issues like the rights of third parties, provision of security for the claim and release from arrest, wrongful arrest and its effects, possibility of re-arrest, re-arrest with leave of court and then re-arrest and risk management.

\subsection{Rights of Third Parties}

Once the ship or property is arrested, it comes under the custody and not the possession of the Admiralty Marshal. A pre-arrest right or remedy of a third party based on possession is not affected ${ }^{49}$. As far as a third party's right is concerned, the Marshal can apply to the court for direction on what to do concerning the right. In The Queen of the South ${ }^{50}$, the port authority's right to detain the ship which was under the custody of the Marshal was preserved. In this case, the port authority was allowed to receive payment for its outstanding dues from the proceeds of sale of the ship by the Marshal before other maritime claimants. In The Mardina Merchant ${ }^{51}$, an application by the port authority to the Admiralty Marshal for direction to move a ship from her place of arrest to another place was granted. The vessel in this case was arrested by various claimants and had remained under arrest for a while, causing interference with the working of the port thereby resulting to financial loss to the port and owners of the berth. If the operation of the port is affected, the court has inherent jurisdiction to give directions to the Admiralty Marshal as it thinks fit.

By schedule 1 of the Civil Procedure Rules of England 1998, third parties whose rights are adversely

\footnotetext{
47 Aleka Mandaraka-Sheppard, 117.

48 R. 61.5(4) Civil Procedure Code 1998.

49 AlekaMandaraka-Sheppard, 118.

50 (1968) 449.

51 (1975) 1 WLR 147.
}

affected by an arrest of a ship can intervene, but any other interference with the arrest amounts to contempt of court. Any other person interested in the property under arrest or proceeds of its sale may be made party to any claim in rem against the property or proceeds where the court considers it would be just and convenient $^{52}$. In a situation where the ship is under arrest but the cargo on board it is not, and those interested in the cargo wish to secure its discharge, they may request the Marshal to take appropriate steps to do so subject to a written undertaking to pay on demand, the Marshal's fees and expenses to be incurred by him.

\subsection{Provision of Security for the Claim and release from Arrest}

When a ship is arrested, the defendant or the person interested in it may acknowledge service and contest the arrest without submitting to the jurisdiction, or acknowledge service and submit to the jurisdiction and provide security ${ }^{53}$ for the release of the vessel from arrest. Where he chooses to do nothing, the Admiralty Marshal will put the ship for sale. Where security is provided, it may be placed either as bail in court or kept as an undertaking on behalf of the person interested in the ship. The amount of security for release of a ship must be reasonable and its assessment proximate. In The sovereign Explorer ${ }^{54}$, it was held that the form of guarantee provided is at the discretion of the court ${ }^{55}$. The court may in the interest of business, instead of ordering an arrest, order a financial security. In Comastrans S.A $v$ Corlett Actividades Maritimas Lda \& MV Nadine Corlett ${ }^{56}$, Forbang J. of the High Court of Buea, after having declined to make an outright order for the arrest of the vessel, MV Nadine Corlett berthed at the Tiko sea port until the motion for the arrest of the vessel was endorsed by the relevant maritime officials ${ }^{57}$, held that

52 R. 61.8(7) of the English Civil Procedure Rules 1998.

53 Acknowledgement and provision of security in any case will not be construed as acknowledgement of liability or waiver of any defence or any right to limit liability. See Article 2(3) of the 1999 Convention of the Arrest of Ships.

54 (2001) 1 Lloyd's Rep. 60.

${ }^{55}$ The court will exercise this discretion only when there exist no agreement between the parties as to the sufficiency and form of security. See Article 4(2) of the 1999 Convention on the Arrest of Ships.

56 Suit No HCF/166/05-06/2M/06.

57 The Learned Judge by declining to make such an order was simply implementing the provisions of the statute regulating maritime activities in Cameroon. (See Article 120 of CEMAC Marine Merchant Code 2001). Article 150 of the 
it will be inequitable to allow the ship sail out of the port before the determination of the plaintiff's claim. He then ordered financial security from the owner of the ship in lieu of arrest. He said:

In order to water down the harsh economic effect that the arrest of a ship may cause to the ship owner, the modern and common practice has been for the courts to order security from the ship owner in lieu of arrest as a just, equitable and valuable measure. Such guarantee is usually in the form of a written undertaking or a bank guarantee ${ }^{58}$.

\subsection{Wrongful Arrest and its Effects}

The Arrest Convention of $1999^{59}$ is silent as to what may amount to wrongful arrest. We can hold here that the Convention has consequently left in the hands of individual States, the matter of remedy in cases of wrongful arrest. The CEMAC legislation ${ }^{60}$ is also silent as far as wrongful arrest is concerned. In Cameroon this void can easily be remedied by turning to foreign laws for assistance ${ }^{61}$.

Under English law, the ship owner or demise charterer must show that the arresting party was guilty of malice or gross negligence ${ }^{62}$. In the Evangelismos, the Privy Council dealt with the conduct required to be proved by the ship owner in order to succeed in his

2012 CEMAC Marine Merchant Code is a replica of Article 120 of the old Code.

58 See Yanou A. Micheal, Practice and Procedure in Civil Matters in the Courts of Records in Anglophone Cameroon (Wusen Publishers, Nigeria, 2012) 52.

59 This Convention in its Article 6 permit the court to require the claimant to put up security in the event of wrongful or unjustified arrest, as a condition of arrest. The silence of this law as to what act(s) of the arresting party constitute wrongful arrest, is the reason why we have turned to foreign jurisdiction for assistance.

60 Matters of arrest are treated in the law in Book II, Part VI, Chapters I \& II of the Code. The first chapter covering articles 144 to 156 deals with arrest as a conservatory measure (saise conservatoire) and the second chapter focuses on arrest to enforce a judgement (saisie vente) and runs from articles 157 to 174.

${ }^{61}$ Article 68 of Law No. 96/06 of $18^{\text {th }}$ January, 1996 revising the 1972 Constitution of Cameroon is helpful. The Article states that the legislation applicable in the Federal State of Cameroon and in the Federated States on the date of entry into force of this Constitution shall remain in force in so far as it is not repugnant to this Constitution, and as long as it is not amended by subsequent laws and regulations. It is important to note that these laws which were applicable in the Federated states mostly foreign taking their roots from Britain and France.

62 See The Evangelismos(1858) 12 Moo PC 352. claim for damages in case of wrongful arrest. In the process of investigation, the court has to ask the following question: is there or is there no reason to say that the action was so unwarrantably brought, or brought with so little colour, or so little foundation, that it rather implies malice on the part of the plaintiff, or gross negligence which is equivalent to it? In resolving this question, it was held that there was no malice on the part of the arresting party, hence the action for damages dismissed. But in Gulf Azov v Idisi ${ }^{63}$, the court held that there was clear evidence of wrongful detention of both the ship and crew in Nigeria and the arrest of the ship for an unsustainable claim.

It is clear from these cases that under common law, in order for the defendant to claim damages for wrongful arrest he must prove mala fide or gross negligence on the part of the arresting party. In Cameroon, maritime legal practitioners should lay more emphasis on Article $6^{64}$ of the 1999 Convention in case they do not want to go beyond national borders for solutions in cases of wrongful arrest.

\subsection{Possibility of re-arrest}

The Arrest Convention of 1999 makes it clear that once a ship has been arrested and released on security, the ship shall not thereafter be re-arrested ${ }^{65}$. By this provision, once judgement on the merits has been given and security obtained for the same cause of action, there can be no re-arrest. The courts had, in mid-19 ${ }^{\text {th }}$ century held that there cannot be a re-arrest once judgement has been final ${ }^{66}$. In this case ${ }^{67}$, Dr Lushington set aside a warrant of arrest by which the claimant sought to obtain further security. In doing so, the court held that the bail represented the ship and it would be absurd to contend that one could arrest a

${ }_{64}^{63}$ (2001) 1 Lloyd's Rep. 727.

64 This Article captioned 'protection of owners and demise charterers of arrested ships' provide in its paragraph (1) that the court may as a condition of the arrest of a ship, or permitting an arrest already effected to be maintained, impose on the claimant who seeks to arrest or has procured the arrest of the ship the obligation to provide security of a kind and for an amount, and upon such terms, as may be determined by that court for any loss which may be incurred by the defendant as a result of the arrest, and for which the claimant may be found liable.

65 Article 5(1). See further paras (a) \& (b) for exceptional situations where a re-arrest may be allowed.

${ }^{66}$ The Kalamazoo(1851) 15 Jur 885 at 886 . In this case, the bail given for collision claim was found to be insufficient after ${ }^{67}$ Ibid. judgement. 
ship, take bail to any amount, and afterwards arrest her again for the same cause of action ${ }^{68}$. The philosophy behind this reasoning is that the cause of action had become merged in the judgement and therefore res judicata ${ }^{69}$.

Comparing these decisions with the provisions of the 1999 Arrest Convention, the decision in The Kalamazoo will not stand today. This is so because under the Convention a re-arrest is possible when the nature or amount of security is inadequate ${ }^{70}$, or the person who provides the security is not or unlikely to be able to fulfil his obligation ${ }^{71}$. To avoid a re-arrest which will undoubtedly require additional cost on the part of the party requesting the re-arrest a careful assessment of the security is primordial.

\subsection{Re-arrest and Risk Management}

Security is provided in most cases by agreement and in which case the claimant releases the ship from arrest and promises not to re-arrest it. To this end, a further arrest will not only be a breach of agreement, but will also be against good faith. However, there can be re-arrest where circumstances render the agreement impossible of performance. In Westminster Bank Ltd $v$ West of England Association ${ }^{72}$, it was held that when there has been a mistake on the amount of bail, or there is a question of solvency of the surety, the issue of bail may be reopened. It follows that rearrest may be allowed in situations where the security given is by way of personal guarantee which turns out to be inoperative. As stated by Foskett ${ }^{73}$, an agreement of compromise normally discharges all original claims and counterclaims unless it expressly provides for their revival in the event of breach.

The rule that the bail represent the ship, so there should be no re-arrest is therefore not without exceptions. The justification for this rule per Llyod $\mathrm{LJ}^{74}$ is to avoid oppression and unfairness on the

${ }^{68}$ See the dictum of Dr. Lushington in The WildRangers (1863) Lush 553, (1862) 1 New Rep. 132.

69 This refers to a matter on which the court has already reach a decision binding on the parties which they cannot question again. See also The Point Breeze (1928) 30 LIL Rep 229 and The Alletta (1947) 1 Lloyd's Rep. 40.

70 Article 5(1) (a).

71 Article 5(1) (b).

72 (1933) 46 LIL Rep. 101.

73 Foskett, The Law and Practice of Compromise $5^{\text {th }} \mathrm{Ed}$. (London LLP, 2005) 150.

74 In The Aretic Star(1985) the Time, 5 February 2010. This same view was held by Steel J, in The Ruta(2000) 1 Lloyd's Rep. 359. claimant. The same would apply where the security given is not a bail, but a personal undertaking such as a guarantee. In such situations where it will be impossible to realise the security, the proper way to manage the risk may be to permit a re-arrest or the ship appraised and sold by the court. This is to say that a re-arrest/appraisal and sale of the vessel by the court is an available risk management mechanism opened to the claimant as a last resort.

\section{Appraisal and sale by the court}

The question has been whether an order for the appraisal and sale of a ship under arrest in an action in rem normally arises only in case of default of appearance or defence? It has been common practice for the court to make such an order on the application of the plaintiff(s) on the grounds that, unless such an order is made, the security for his or their claim(s) will be diminishing by the continuing costs of maintaining the arrested ship, to the disadvantage of all interested in the ship, including if they have any residual interest, the defendants themselves ${ }^{75}$. In $U A B$ Garant $v$ The AleksandrKsenofontov ${ }^{76}$, the plaintiff's application for appraisal and sale of an arrested ship was granted based on the assertion that the vessel was deteriorating in value because of the costs of arrest and lack of security provided by the owner.

Appraisal of a ship before its sale is a mechanism adopted to prevent a below the market value sale of the res in the state in which it is. The appraisal is done by the Marshal/Sheriff. When the proceeds of sale are enough to satisfy creditors, the issue of priority is not discussed. Priority of payment out of the court fund becomes of essence when the fund in the court representing the ship is insufficient to satisfy all interested parties.

\subsection{Priorities in payment of claims out of Court Fund}

When the proceeds of sale are not enough to satisfy all claimants, the priorities of relatively smaller claims such as the wages claims of master and crew, the disbursement claims of master, the claims of necessary men and of ship repairers, the fees and costs of the Admiralty Marshal, and a claim for expenses incurred for arrest as well as appraisal and sale of the

\footnotetext{
${ }^{75}$ Per Brandon J. in The Mytro(1977) 2 Lloyd's Rep. 243 at 260. ${ }^{76}$ (2007) 1 NZLR 60.
} 
vessel will invariably engender complex legal problems $^{77}$.

The right of a maritime creditor to the property of his debtor by an in rem action is a potent and indeed a valuable legal weapon ${ }^{78}$. In such a case, the res may be the ship, cargo and/or freight. Once an in rem action is instituted against the ship and the claimant has been awarded judgement and obtained an order for the appraisal and sale of the res, the next question is whether the fund representing the res is sufficient to satisfy all the various claims and if not which shall be paid in priority over the other.

Before examining the issue of priority, it is trite to consider the claim of port or harbour authority that has been vested by statute with the power of detention and sale. The reason for considering first the claims of the port or harbour authority is that their claim is statutorily protected and have been said to fall outside the ambit of priorities ${ }^{79}$.

\subsubsection{Statutory Rights of Port Authorities of detention and sale}

At common law, certain public bodies such as dock and harbour authorities have, by statute been given the power to detain and sell a vessel when her owner has failed to pay dock dues or any outstanding debts, or has failed to indemnify them for damage caused to their property ${ }^{80}$. To enforce their rights, the authorities can invoke the provisions of the 1874 Harbour, Docks and Piers Clauses Act, which empowers them to arrest and sell any vessel or wreck within the premises of the port for unpaid dues or damage caused to their property. To Sheen J., such bodies have been given the simple means of self-help to recover sums of money due them ${ }^{81}$.

Two possible questions may arise concerning the rights of port authorities where the relevant ship comes under the custody of the Admiralty Marshal: (1) is the port authority's statutory right of detention preserved? (2) Is the claim of the port authority

\footnotetext{
${ }^{77}$ Susan Hodges and Christopher Hill, Principles of Maritime Law (LLP, London 2001) 445.

78 D.C. Jackson, Enforcement of Maritime Claims, $2^{\text {nd }}$ Ed. (LLP, London 1996) 126.

${ }^{79}$ Susan Hodges and Christopher Hill, 446, referred to this claim as a paramount claim and must be paid in full even when the ship owner is entitled to limit his liability as against other claimants. See also Aleka Mandaraka-Sheppard, 135.

${ }^{80}$ Ibid 451.

${ }^{81}$ The Blitz(1992) 2 Lloyd's Rep. 441 at 442.
}

transferred to the court fund with its preferential treatment over and above other preferential claims? These two related questions have been aptly addressed judicially. In Emillie Millon ${ }^{82}$, the Court of Appeal held that the claim of the port authority could not be transferred to the court fund and that the right of detention should be maintained until the port was paid regardless of maritime liens. The court could not therefore order the sale and delivery of the ship to the purchaser. In The Sea Spray ${ }^{83}$, the question of priorities between the port authorities for their expenses incurred in respect of raising the wreck of the ship and the claim of the barge for damages suffered due to collision was resolved by allowing the port authority to sell the ship, pay itself and deposit the balance of the proceeds with the court. Similarly in The Ousel ${ }^{84}$, the judge accepted obiter that the sale by the port authority gives title free of encumbrances but three and a half decades later it was held that the port authority could only pass title to a purchaser of the ship free of mortgages but not free of maritime liens ${ }^{85}$. The court's reasoning here was that the purchaser could not be expected to investigate the registry of interests on the ship before acquiring it from the harbour authority.

In response to the questions above, it is clear that the claim of port authorities though arising from the same source of claims of other claimants does not effectively fall within the ambit of priorities and has preference over and above any other claim.

After having satisfied the claim of the port authorities what is left of the proceeds of sale under the control of the court constitutes the court fund. The court will then proceed to determine the distribution of the fund following the order of priorities.

\subsubsection{Order of Priorities in the distribution of Fund by the Court}

The court has broad discretionary powers taking into account considerations of equity, public policy and commercial expediency with the ultimate aim of

${ }^{82}$ (1905) 2 K.B. 817.

${ }^{83}$ (1907) 133.

${ }^{84}$ (1957) 1 Lloyd's Rep. 151.

${ }^{85}$ The Blitz (1992) 2 Lloyd's Rep 441 at 442. For more knowledge on the statutory powers of port authorities for detention and sale of ship see AlekaMandaraka-Sheppard (2007), Modern Maritime Law and Risk Management. pp. 136-142. See also Susan Hodges and Christophe Hill (2001), Principles of Maritime Law. pp. 452- 463. 
doing justice in the circumstances of each case ${ }^{86}$. The court follows this order of priorities:

1. The fees and expenses of the Admiralty Marshal: Where the port authority failed to enforce its right of detention and sale, the Admiralty Marshal's fees and expenses will be paid as a first charge on the fund realised from the sale of the ship. In addition, he is paid all expenses incurred for effecting the arrest of the vessel, maintaining such arrest and for ensuring that the vessel is kept in such a condition that she may be sold at the highest price.

2. The cost incurred for arresting the ship, for appraisement and sale and for the administration of the fund. These costs are paid irrespective of the priority of the substantive claim held by party/parties who had incurred the costs. As producers of fund, they are given a charge second to the Admiralty Marshal, on the proceeds of sale.

3. Maritime liens: These are privilege rights peculiar to the ordinary doctrine of liens under common law ${ }^{87}$. The roots of maritime liens stretch far back to the maritime law of the ancient world and particularly to the medieval European lex maritime $^{88}$. It is a secret charge upon the vessel enforceable against the world irrespective of who is in possession. The reason why this privilege cannot be defeated by subsequent change in ownership is that it is a right vested in the res rather than a right dependent upon identity of the owner or on the institution of the in rem action. It is a personal privilege which ensued to the sole benefit of the maritime lien and for this reason, an assignee of a lien for wages cannot claim the benefit of the privileges held by the assignor ${ }^{89}$.

4. Possessory lien: The efficacy of this lien essentially depends upon possession as the name indicates. In shipping law, the term is synonymous with a ship repairer's claim ${ }^{90}$. Once the vessel is in the possession of a ship repairer, he is entitled to

${ }^{86}$ Justice Steel in The Ruta (2000) 1 Lloyd's Rep. 359.

87 Susan Hodges and Christopher Hill, 447.

88 William Tetley, 'Maritime Liens in the Conflict of Laws' an Art. published in, Law and Justice in a Multistate World, Essays in Honour of Arthur T. von Mehren (Transnational Publishers Inc., New York 2010) 440.

${ }^{89}$ Per Waung J. in The Sparti (2000) 2 Lloyd's Rep. 618 at 620.

${ }^{90}$ Susan Hodges and Christopher Hill, 493. See also Meeson N (2000), Admiralty Jurisdiction in Practice $2^{\text {nd }}$ Ed. (LLP London). It should be noted here that the ship repairer's claim under civil law is considered a maritime lien and will not be lost should the ship sail out of the ship yard without paying the cost of repairs. hold on to it as security for any claim he might have against her owners for the cost of repairs. Possession is not lost when the ship is handed over to the Admiralty Marshal for the purpose of effecting an arrest. After sale, the repairer's right against the fund is preserved by the Marshal.

In the issue of priority, maritime liens attached on the vessel before possessory lien of ship repairer will take priority over the possessory but subsequent maritime liens will not. In competition for priority as between possessory and statutory liens, the former takes precedence over all earlier and subsequent statutory liens ${ }^{91}$.

5. Mortgages: A possessory lien prevails over a mortgage claim whether the mortgage is created before or after the lien. Mortgagees are paid in the order of registration, while equitable mortgagees are last in order of priority.

6. Claimants who become secured creditors by the issue of the in rem claim form.

7. Claimants who have obtained a judgement in personam against the ship owner or the res will be last.

8. The balance, if any, will be paid to the owner of the ship.

Subject to the broad discretionary approach of the court to do what is just in each case, if all liens are in the same category, they rank paripassu ${ }^{92}$, except in relation to salvage where the last in time may take priority on the justification that the ship is saved by the salvor for the benefit of other claimants.

\section{Conclusion}

Ship arrest in Cameroon is governed by the CEMAC Marine Merchant Code 2012 and the 1999 International Ship Arrest Convention. These texts provide the mechanisms for arresting a ship within the territorial waters of Cameroon. In Cameroon the courts charged with the responsibility of exercising admiralty jurisdiction are the Courts of First Instance and the High Courts. For a vessel to be arrested, the parties interested in the arrest (the claimant(s)) must have prayed the competent court to issue an in rem form. The form is forth with served upon the vessel by affixing it on a visible portion of the vessel or service is done on the defendant (owner(s) of the vessel) or his or their solicitor. Arrest of a ship proper

\footnotetext{
${ }^{91}$ See The Gustaf(1862) Lush. 506. See also Susan H. \& Christopher H. supra at 515.

92 See The Steam Fisher (1926) 73.
} 
is done by a competent maritime authority following notification to that effect by a competent court. In Cameroon ship arrest serves one of two purposes: to provide security for a claim on the one hand and on the other hand to execute a court judgement. Third parties' rights are often taken into account when a vessel is arrested. An arrest aimed at executing a court known in French as saisie vente is followed by appraisal, sale and distribution of the proceeds of sale of the vessel. It is clear from the content of this article that Cameroon has a straight and a simple procedure for the arrest of a ship within her territorial waters.

\section{Bibliography}

Books

1. Aleka Mandaraka-Sheppard (2007), Modern Maritime Law and Risk Management.

2. Foskett (2005), the Law and Practice of Compromise $5^{\text {th }}$ Ed. LLP London.

3. Jackson, D. C (1996), Enforcement of Maritime Claims, 2nd Ed. LLP, London.

4. Joseph Mbah-Ndam (2003), Practice and Procedure in Civil and Commercial Litigation, Press Universitaires d'Afrique.

5. Meeson N (2000), Admiralty Jurisdiction in Practice $2^{\text {nd }}$ Ed. (LLP London

6. Susan Hodges and Christopher Hill (2001), Principles of Maritime Law LLP, London.

7. Yanou A. Micheal (2012), Practice and Procedure in Civil Matters in the Courts of Records in Anglophone Cameroon (Wusen Publishers, Nigeria,

\section{Articles}

1. William Tetley, 'Maritime Liens in the Conflict of Laws' an Art. Published in, Law and Justice in a Multistate World, Essays in Honour of Arthur T. von Mehren (Transnational Publishers Inc., New York 2010) 440.

2. Olisa Agbakoba (2001), "Priorities of Claims arising from sale of Vessels". In Maritime Seminar for Judges, MIJ Professional Publishers Ltd. Lagos.

3. Chidi Ilogu L (1995)., "Essentials of Admiralty Practice and Procedure in Nigeria". In Maritime Seminar for Judges, MIJ Professional Publishers Ltd., Lagos.

Seminar papers

1. Feh Henry Baaboh, 'Ship arrest as an Executory Measure in Cameroon'. A paper presented at the $5^{\text {th }}$ Members Meeting of SHIPARRESTED.COM. Riga in 2008.

2. Feh Henry Baaboh, 'Ship Arrest in Cameroon as a Conservatory Measure' a Paper Presented at the $3^{\text {rd }}$ General Meeting of SHIPAERRESTED.COM. Marseilles, France in 2006

3. Anga and Emuwa, 'ship Arrest in Nigeria' presented during a workshop on "Evolving a Sustained Pipeline Policy Amidst best Practice in Nigeria" organized by the Nigeria Society of Maritime Researchers, September 2007, University of Lagos Nigeria. 